\title{
Inactivation of oestrogen receptor in vitro by nuclear dephosphorylation
}

\author{
Ferdinando AURICCHIO, Antimo MIGLIACCIO and Andrea ROTONDI \\ Istituto di Patologia Generale, I Facoltà di Medicina e Chirurgia dell'Università di Napoli, \\ Via S. Andrea delle Dame 2, 80138 Napoli, Italy
}

(Received 29 May 1980/Accepted 10 September 1980)

\begin{abstract}
1. Nuclei of the calf uterus are endowed with an activity inactivating crude oestrogen-receptor complex. This activity has been partially purified. It shows a very high affinity for the oestrogen-receptor complex $\left(K_{\mathrm{m}}=0.8 \times 10^{-9} \mathrm{~mol}\right.$ of specific $\left[{ }^{3} \mathrm{H}\right]$ oestradiol-17 $\beta$-binding sites/l) as well as for the oestrogen-free receptor $\left(K_{\mathrm{m}}=\right.$ $1.5 \times 10^{-9} \mathrm{~mol}$ of specific $\left[{ }^{3} \mathrm{H}\right]$ oestradiol-17 $\beta$ binding sites $\left./ 1\right)$. 2 . The nuclear receptorinactivating activity is enhanced by dithiothreitol and inhibited by several phosphatase inhibitors as well as by 4-nitrophenyl phosphate, a well known phosphatase substrate. This inhibition shows that a dephosphorylation process is required for the receptor inactivation. 3. The purified nuclear activity also inactivates pure receptor and phosphatase inhibitors prevent this inactivation. From these observations it appears that receptor inactivation is due to a nuclear phosphatase directly acting on the oestrogen receptor. 4. The nuclear localization of the receptor-inactivating activity, its high affinity for specific oestrogen binding sites and, as previously reported, its presence only in oestrogen target tissues suggest that this activity is the same as that involved in the nuclear loss of the receptor observed in intact cells.
\end{abstract}

The half-life of the uterus cytosol oestradiol receptor is about 5 days (Sarff \& Gorski, 1971). In contrast, a rapid loss of this receptor, measurable in minutes, is observed after its nuclear translocation (Horwitz \& McGuire, 1978) after the binding of hormone to the cytosol receptor. The nature of this rapid nuclear inactivation is unknown although studies on intact cells have shown that the nuclear loss of the receptor is required for some hormonal responses, e.g. replenishment of cytosol oestrogenbinding activity (Rochefort et al., 1972; Clark et al., 1973) and induction of the progesterone receptor (Horwitz \& McGuire, 1978).

With a cell-free system, there has been found in nuclei of mouse uterus and mammary gland an activity capable of very rapid inactivation of oestradiol-free and oestradiol-bound cytosol receptor as well as of the nuclear receptor (Auricchio et al., 1980). This activity is present only in nuclei from oestrogen target-tissues. The involvement of a dephosphorylation process in the inactivation of receptor by the nuclear activity has been suggested (Auricchio \& Migliaccio, 1980).

Since a study of the receptor inactivation by this nuclear activity could give information on the mechanism responsible for the nuclear loss of the receptor observed in intact cells, we have purified this activity from calf uterus nuclei. It shows an exceptionally high affinity for the crude $\left[{ }^{3} \mathrm{H}\right]$ oestrogen-bound receptor as well as for the oestrogen-free receptor; this fact supports a physiological role of the receptor-inactivating activity. A detailed study of inhibitors of this activity led us to conclude that it is a phosphatase(s). Experiments performed with partially purified inactivating activity and isolated calf uterus oestrogen receptor strongly suggest that the inactivation of receptor is due to dephosphorylation of the receptor itself.

This paper is dedicated by Ferdinando Auricchio to Professor Gerhard Pfleiderer for his 60th birthday.

\section{Experimental}

Materials

Reagent grade materials were used in all experiments. Dithiothreitol, egg albumin, calf-thymus DNA and oestradiol-17 $\beta$, were from Sigma Chemicals Co., St. Louis, MO, U.S.A. CM-cellulose was purchased from Boehringer, Mannheim, Germany; $\left[6,7-{ }^{3} \mathrm{H}\right]-$ oestradiol- $17 \beta(60 \mathrm{Ci} / \mathrm{mmol})$ and $\left[2,4,6,7-{ }^{3} \mathrm{H}\right]$ oestradiol-17 $\beta(85 \mathrm{Ci} / \mathrm{mmol})$ were obtained from The Radiochemical Centre, Amersham, Bucks., U.K. 


\section{Buffers}

The following buffer solutions were used: $10 \mathrm{mM}$ Tris/HCl, pH 7.4, containing $1 \mathrm{~mm}$-dithiothreitol (TD-buffer), TD-buffer plus $1 \mathrm{mM}$-EDTA (TEDbuffer), TD- and TED-buffer plus $0.25 \mathrm{M}$-sucrose (TD-and TED-sucrose buffers).

\section{Homogenization and fractionation}

Mature calf uteri were collected at the local slaughterhouse as soon as the animals were killed, and kept on crushed ice. Uteri were stripped of connective tissue and stored in liquid nitrogen up to the time of use, but for no longer than 1 week. After thawing at $0^{\circ} \mathrm{C}$, uteri were minced in a meat grinder and mixed with 4-5 vol. of cold TD- or TED-sucrose buffer and homogenized by a previously reported procedure (Rotondi \& Auricchio, 1979) modified in the following way: eight or nine bursts at $100 \mathrm{~V}$, lasting $20 \mathrm{~s}$ each at $1 \mathrm{~min}$ intervals, were applied with an Ultra-Turrax homogenizer (Janke and Kunkel Co.). The $750 \mathrm{~g}$ pellet was obtained by centrifugation of the homogenate at $2{ }^{\circ} \mathrm{C}$ for $10 \mathrm{~min}$. Cytosol was prepared either from the homogenate or from the $750 \mathrm{~g}$ supernatant by centrifugation at $150000 \mathrm{~g}$ for $45 \mathrm{~min}$ at $2^{\circ} \mathrm{C}$ in a L2-65 Spinco-Beckman ultracentrifuge with a Ti 50 rotor. Nuclei were purified from the $750 \mathrm{~g}$ pellet as follows: the pellet was suspended in TED-sucrose buffer, layered on top of TED-buffer plus $2.2 \mathrm{M}$ sucrose and centrifuged at $160000 \mathrm{~g}$ for $75 \mathrm{~min}$ at $2{ }^{\circ} \mathrm{C}$ in a SW $41 \mathrm{Ti}$ rotor. Nuclear extracts were prepared from nuclei suspended in $2 \mathrm{ml}$ of TEDbuffer, slowly shaken at $0^{\circ} \mathrm{C}$ for $30 \mathrm{~min}$, then sonicated with a 350G sonifier (PBI Ultrasonics). Four bursts at power 10 , tuning 2 , were applied, lasting $15 \mathrm{~s}$ each at $1 \mathrm{~min}$ intervals. The sonicated sample was centrifuged at $150000 \mathrm{~g}$ for $10 \mathrm{~min}$ at $2^{\circ} \mathrm{C}$ and the supernatant ('nuclear extract') utilized.

\section{Preparation of $\left[{ }^{3} \mathrm{H}\right]$ oestradiol-17 $\beta$-receptor-cytosol complex}

The complex was obtained by incubation of $5-20 \mathrm{ml}$ of calf-uterus cytosol with $12 \mathrm{nM}-\left[{ }^{3} \mathrm{H}\right]-$ oestradiol-17 $\beta$ alone (high sp. radioactivity $\left[{ }^{3} \mathrm{H}\right]$ oestradiol-17 1 ) and in the presence of a 100 - or 1000 -fold excess of radioinert oestradiol (low sp. radioactivity $\left[{ }^{3} \mathrm{H}\right]$ oestradiol $\left.-17 \beta\right)$ at $0^{\circ} \mathrm{C}$ for $2 \mathrm{~h}$.

\section{Pure calf-uterus oestrogen receptor}

Calf-uterus oestrogen receptor was isolated and its purity checked as previously reported (Puca et al., 1980).

\section{Specific oestrogen-binding activity}

This activity was determined in duplicates as the difference between binding at $0^{\circ} \mathrm{C}$ for $2 \mathrm{~h}$ of high and low specific radioactivity $\left[{ }^{3} \mathrm{H}\right]$ oestradiol- $17 \beta$. Bound oestradiol was separated from free hormone by dextran-coated charcoal ( $1 \%$ Norit A, $0.01 \% \mathrm{~T}$ 70 dextran, $0.5 \%$ gelatine in TED-buffer) treatment in the following way. A $0.2 \mathrm{ml}$ portion of dextrancharcoal suspension was added to $0.2 \mathrm{ml}$ of cytosol. The mixture was incubated at $0^{\circ} \mathrm{C}$ for $5 \mathrm{~min}$ and centrifuged at $800 \mathrm{~g}$ for $5 \mathrm{~min}$. A $0.2 \mathrm{ml}$ portion of the supernatant was added to the scintillation liquid for radioactivity counting.

Purification of calf-uterus oestrogen-receptor-inactivating activity

Calf uterus $(250 \mathrm{~g})$ was homogenized in TEDsucrose buffer and centrifuged at $750 \mathrm{~g}$ at $2{ }^{\circ} \mathrm{C}$ for $15 \mathrm{~min}$. The pellet was suspended in $150 \mathrm{ml}$ of TED-buffer, slowly shaken at $0^{\circ} \mathrm{C}$ for $30 \mathrm{~min}$, sonicated and centrifuged by the procedure reported for the nuclear extract. The supernatant, ' $750 \mathrm{~g}$ pellet extract', was applied to a CM-cellulose column $(13 \mathrm{~cm} \times 1 \mathrm{~cm}$ diameter) equilibrated with TEDbuffer. The sample was then eluted with $1.5 \mathrm{vol}$. of TED-buffer plus $0.2 \mathrm{M}-\mathrm{NaCl}$. This fraction contains the purified oestrogen-receptor-inactivating activity. No additional activity is eluted by buffer containing higher $\mathrm{NaCl}$ concentrations.

\section{Assay of calf-uterus oestrogen-receptor-complex-} inactivating activity

The activity present in calf-uterus $750 \mathrm{~g}$ pellet extracts, in nuclei, in nuclear extracts or in purified preparations of activity inactivating the oestrogen receptor, was assayed by the following standard procedures: calf-uterine cytosol labelled with high and low specific radioactivity $\left[{ }^{3} \mathrm{H}\right]$ oestradiol- $17 \beta$ for $2 \mathrm{~h}$ at $0^{\circ} \mathrm{C}$ was incubated at a concentration of $1 \times 10^{-12} \mathrm{~mol}$ of specific $\left[{ }^{3} \mathrm{H}\right]$ oestradiol- $17 \beta$ binding sites $/ \mathrm{ml}$ of incubation mixture. The incubation was carried out for the indicated times and in the specified buffers at $25^{\circ} \mathrm{C}$ in the absence (control) and in the presence of the inactivating preparation. The reaction was stopped by cooling of the samples at $0^{\circ} \mathrm{C}$. One arbitrary unit is the activity responsible for the loss of $1 \times 10^{-14} \mathrm{~mol}$ of specific binding sites/ min after correction of the loss observed in the control.

In the experiments performed to measure the affinity of purified inactivating activity for receptor the following modifications were introduced; different concentrations of cytosol were added to the incubation mixtures and unlabelled cytosol was added to the incubation mixtures to measure the $K_{\mathrm{m}}$ of the activity for the oestrogen-free receptor.

Radioactivity was measured in a Beckman liquidscintillation counter, by standard procedures with an efficiency of $40 \%$.

Protein and DNA contents were measured by previously reported procedures (Bradford, 1976; Giles \& Meyers, 1965) with egg albumin and calf-thymus DNA respectively, as standards. 


\section{Results}

Inactivation of crude $\left[{ }^{3} \mathrm{H}\right]$ oestrogen-receptor complex by calf-uterus nuclei

Nuclei from calf uterus inactivate the homologous oestrogen-cytosol-receptor complex on incubation at $25^{\circ} \mathrm{C}$ and most of the inactivating activity can be extracted (Fig. 1), a feature that has made purification and characterization of this activity possible.

\section{Purification of receptor-inactivating activity}

The $750 \mathrm{~g}$ pellet extract was prepared from the homogenate of calf uterus $(250 \mathrm{~g})$. The activity present in the $750 \mathrm{~g}$ pellet extract was purified 35 -fold with a yield of $47 \%$ by CM-cellulose chromatography (Table 1 ). The overall purification

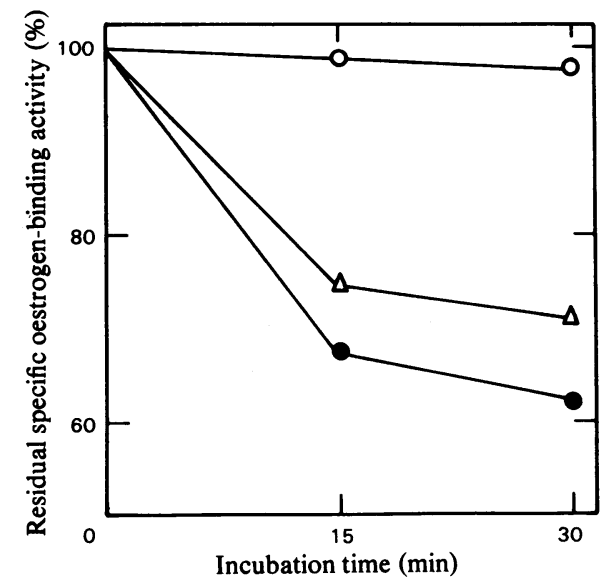

Fig. 1. Time-dependent inactivation of $\left[{ }^{3} \mathrm{H}\right]$ oestradiolreceptor complex by nuclei or nuclear extract from calf uterus

$1 \times 10^{-12} \mathrm{~mol}$ of cytosol specific $\left[{ }^{3} \mathrm{H}\right]$ oestrogen binding sites $/ \mathrm{ml}$ was incubated in TED-sucrose at $25^{\circ} \mathrm{C}$ for the indicated times in the absence $(O)$ and in the presence of either nuclei (DNA/nuclear protein ratio 0.39 , at a concn. of $78 \mu \mathrm{g}$ of $\mathrm{DNA} / \mathrm{ml}$ of incubation mixture) (O) or nuclear extracts $(\Delta)$. The extract was prepared from an amount of nuclei equal to that added as intact nuclei to cytosol. Intact nuclei and cytosol are derived from the same weight of tissue. Before the assay of specific oestrogen-binding activity, cytosol incubated with nuclei was centrifuged at $3200 \mathrm{~g}$ to remove nuclei. over the homogenate, assuming a total recovery of the homogenate activity in the $750 \mathrm{~g}$ pellet extract, is 1450-fold.

Affinity of the purification activity for the $\left[{ }^{3} \mathrm{H}\right]-$ oestrogen-bound and oestrogen-free receptor

The oestrogen-receptor-inactivating activity of a preparation purified from calf uterus was assayed with different concentrations of specific cytosol $\left[{ }^{3} \mathrm{H}\right]$ oestradiol-binding sites to measure the affinity for $\left[{ }^{3} \mathrm{H}\right]$ oestradiol-bound and oestradiol-free receptor (Fig. 2). The $K_{\mathrm{m}}$ averaged from three different experiments is $0.8 \times 10^{-9}$ and $1.5 \times 10^{-9} \mathrm{~mol}$ of specific $\left[{ }^{3} \mathrm{H}\right]$ oestradiol-17 $\beta$-binding sites/ 1 for oestrogen-bound receptor and oestrogen-free receptor respectively. Therefore, the purified activity shows a very high affinity for both forms of oestrogen receptor.

Effect of dithiothreitol on the oestrogen-receptor inactivation by the purified activity

Fig. 3 shows the dependence of the nuclear activity on dithiothreitol concentrations. In the presence of $10 \mathrm{mM}$-dithiothreitol the inactivation rate of the receptor by the nuclear activity is more than two times faster than in the presence of $1 \mathrm{mM}$ dithiothreitol.

Evidence that inactivation of receptor by the purified activity requires a dephosphorylation process

Several phosphatase inhibitors prevent the inactivation of crude $\left[{ }^{3} \mathrm{H}\right]$ oestrogen-receptor complex by the purified nuclear inactivating activity, whereas they have no significant effect on the same complex in the absence of the inactivating activity (Table 2). 4-Nitrophenyl phosphate, a well known substrate of several phosphatases, also inhibits the nuclear activity.

Evidence that the purified activity directly dephosphorylates the oestrogen receptor

Purified activity inactivates pure $\left[{ }^{3} \mathrm{H}\right]$ oestradiolreceptor complex (Fig. 4). It excludes the possibility, present in the previous experiments in which crude receptor was used, that the inactivation of receptor by nuclear activity is mediated by molecules present in cytosol preparations that regulate the receptor activity.

In analogy with experiments performed with

Table 1. Summary of the purification of calf-uterus nuclear activity inactivating the oestradiol receptor

\begin{tabular}{lccccc}
\multicolumn{1}{c}{ Procedure } & $\begin{array}{c}\text { Volume } \\
(\mathrm{ml})\end{array}$ & $\begin{array}{c}\text { Total protein } \\
(\mathrm{mg})\end{array}$ & $\begin{array}{c}\text { Total activity } \\
\text { (arbitrary units) }\end{array}$ & Purification factor & $\begin{array}{c}\text { Yield } \\
(\%)\end{array}$ \\
Homogenate & 1000 & 14070 & - & - & -1 \\
750g pellet extract & 130 & 338 & 2600 & 1 & 100 \\
CM-cellulose & 36 & 4.53 & 1223 & 35 & 47
\end{tabular}

Vol. 194 


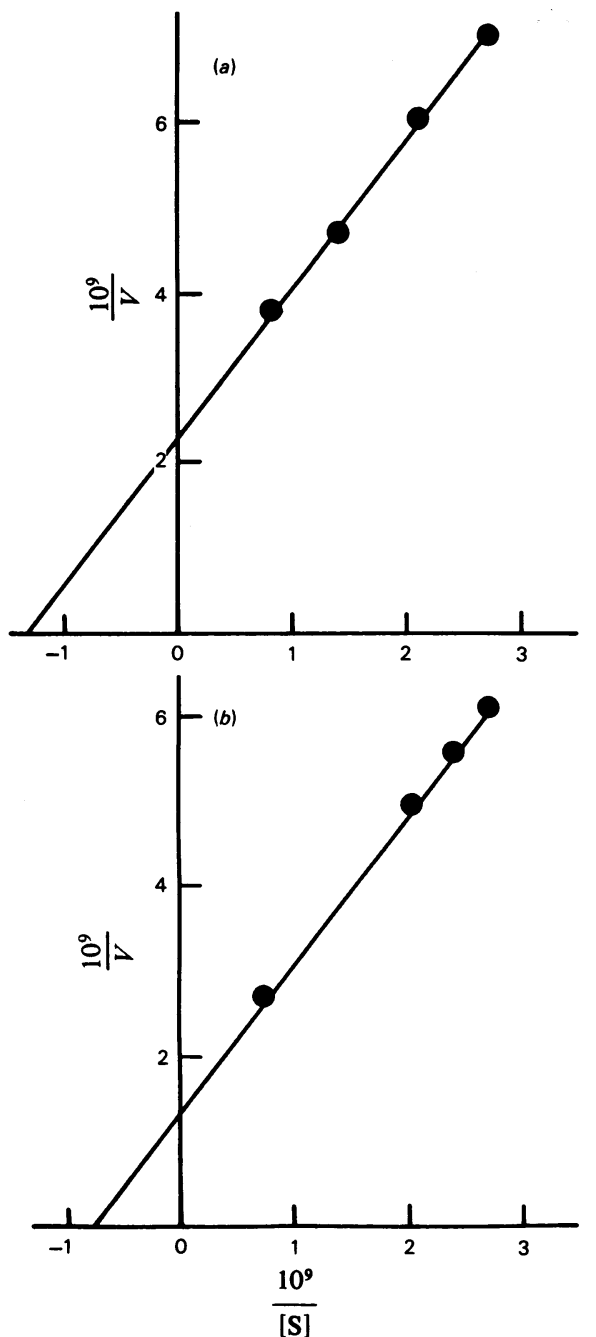

Fig. 2. Double-reciprocal plot of $\left[{ }^{3} \mathrm{H}\right]$ oestradiol-receptor complex and oestrogen-free receptor-inactivating activity purified from calf uterus

The initial activity was assayed in $1.2 \mathrm{ml}$ of TED-buffer containing 4 arbitrary units of the purified receptor-inactivating activity, for $10 \mathrm{~min}$ as described in the Experimental section. $V$ is the change in molarity of specific $\left[{ }^{3} \mathrm{H}\right]$ oestradiol- $17 \beta$ binding sites found and $[S]$ is the molarity of specific $\left[{ }^{3} \mathrm{H}\right]$ oestrogen binding sites incubated with the purified receptor-inactivating activity. The $K_{\mathrm{m}}$ values computed from the experiments presented in the figure are $0.8 \times 10^{-9} \mathrm{~mol}$ of specific $\left[{ }^{3} \mathrm{H}\right]$ oestrogen binding sites $/ 1$, for the $\left[{ }^{3} \mathrm{H}\right]$ oestrogen-bound receptor $(a)$ and $1.3 \times 10^{-9} \mathrm{~mol}$ of specific $\left[{ }^{3} \mathrm{H}\right]$ oestrogen binding sites/l for the oestrogen-free receptor $(b)$.

crude receptor (see Table 2) a complete inhibition of pure receptor-inactivation by phosphatase inhibitors was observed (Fig. 4). These experiments

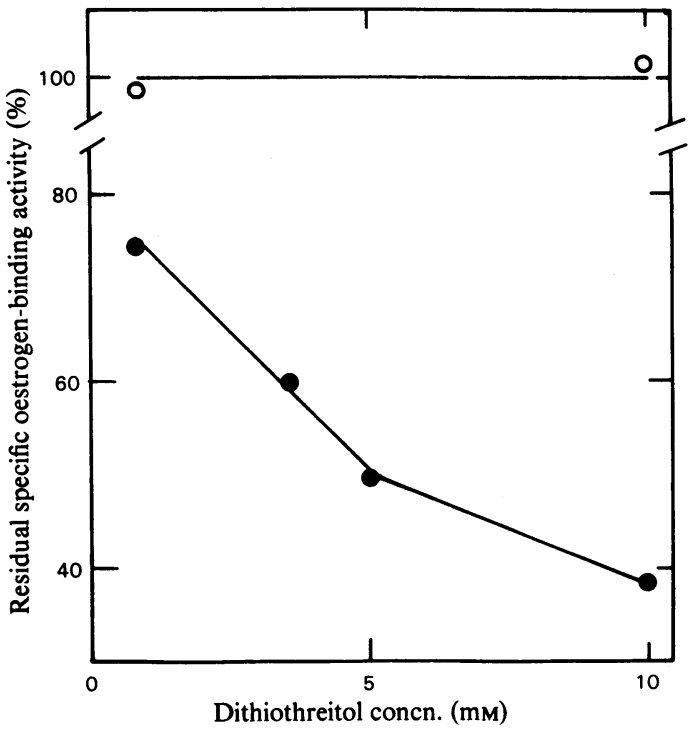

Fig. 3. Dependence on dithiothreitol concentrations of $\left[{ }^{3} \mathrm{H}\right]$ oestrogen-receptor-complex-inactivating activity purified from calf uterus

$1 \times 10^{-12} \mathrm{~mol}$ of cytosol specific $\left[{ }^{3} \mathrm{H}\right]$ oestrogen binding sites $/ \mathrm{ml}$ was incubated in TED-buffer at $25^{\circ} \mathrm{C}$ for $20 \mathrm{~min}$ in the absence $(0)$ and in the presence (๑) of inactivating activity at different concentrations of dithiothreitol.

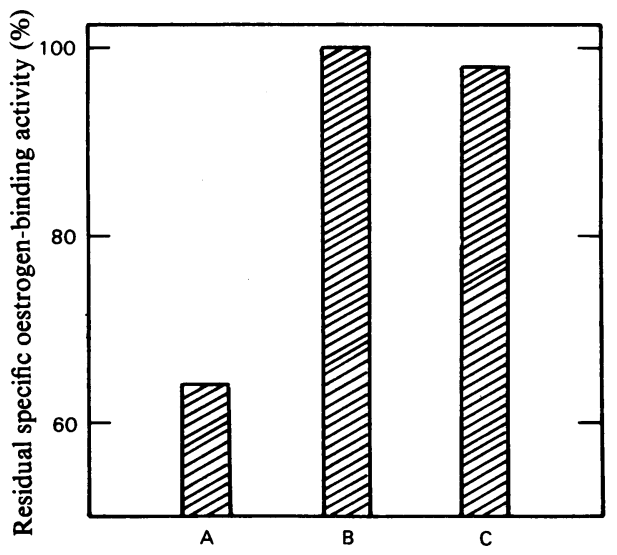

Fig. 4. Effect of phosphatase inhibitors on the inactivation of pure $\left[{ }^{3} \mathrm{H}\right]$ oestradiol-receptor complex by the inactivating activity purified from calf uterus

Pure receptor at a concn. of $1 \times 10^{-12} \mathrm{~mol}$ of $\left[{ }^{3} \mathrm{H}\right]$ oestrogen binding sites $/ \mathrm{ml}$ was incubated at $25^{\circ} \mathrm{C}$ in TED-buffer for $20 \mathrm{~min}$ in the presence of inactivating activity without (A) and with either $20 \mathrm{~mm}$-fluoride (B) or $5 \mathrm{~mm}$-molybdate (C). Results are those averaged from two experiments. 
Table 2. Effect of phosphatase inhibitors and 4-nitrophenyl phosphate on the inactivation of crude $\left[{ }^{3} \mathrm{H}\right]$ oestradiolreceptor complex by the nuclear activity

Calf uterus was labelled at $0^{\circ} \mathrm{C}$ for $2 \mathrm{~h}$ with high and low specific radioactivity $\left[{ }^{3} \mathrm{H}\right.$ ]oestradiol-17 $\beta$, then incubated for $20 \mathrm{~min}$ at $25^{\circ} \mathrm{C}$ in TED-buffer in the absence and in the presence of purified nuclear activity. The results are of single experiments (1st, 2nd and 3rd) together with the corresponding means. In experiments in the presence of $\mathrm{ZnCl}_{2}$, EDTA was omitted from the buffers.

Residual binding activity (\%)

\section{Compound added}

None

$20 \mathrm{mM}$-Sodium fluoride

$5 \mathrm{~mm}$-Sodium molybdate

$0.5 \mathrm{mM}$-Zinc chloride

$1 \mathrm{mM}$-Sodium phosphate

1 mM-Sodium pyrophosphate

$1 \mathrm{mM}$-Sodium 4-nitrophenyl phosphate

\begin{tabular}{rrrr}
\hline \multicolumn{4}{c}{$\begin{array}{c}\text { Receptor in the absence of } \\
\text { nuclear activity }\end{array}$} \\
$\overbrace{1 \text { st }}$ & 2nd & 3rd & Mean \\
96 & 94 & 100 & 97 \\
100 & 100 & 99 & 100 \\
100 & 98 & 95 & 98 \\
89 & 91 & 90 & 90 \\
95 & 100 & 96 & 97 \\
104 & 100 & 108 & 104 \\
99 & 96 & 96 & 97
\end{tabular}

Receptor in the presence of nuclear activity

$\overbrace{\text { 1st 2nd } \quad \text { 3rd Mean }}^{\text {3rd }}$

$\begin{array}{llll}66 & 66 & 68 & 67\end{array}$

$\begin{array}{llll}97 & 105 & 101 & 101\end{array}$

$\begin{array}{llll}106 & 100 & 99 & 102\end{array}$

$\begin{array}{llll}91 & 100 & 94 & 95\end{array}$

$\begin{array}{llll}96 & 101 & 95 & 97\end{array}$

$97 \quad 101 \quad 93 \quad 97$

$\begin{array}{llll}94 & 97 & 93 & 95\end{array}$

strongly suggest that the receptor itself, during the inactivation process, is dephosphorylated.

\section{Discussion}

The requirement of nuclear inactivation of oestrogen receptor for hormonal responses has been assessed by studies in which the nuclear loss was followed in intact cells (Sarff \& Gorski, 1971; Horwitz \& McGuire, 1978; Rochefort et al., 1972). Nevertheless, the process responsible for the nuclear loss is still unknown. The cell-free system used in the present work, as well as in previous experiments (Auricchio et al., 1980; Auricchio \& Migliaccio, 1980), offers obvious advantages over the intact-cell system for the study of the mechanism responsible for nuclear inactivation of receptor, although it does not allow us to conclude that the receptor inactivation occurs within nuclei. Nevertheless, this possibility is strongly supported by the evidence previously reported (Auricchio et al., 1980) that mouse-uterus nuclear receptor is inactivated by this nuclear activity.

Previous observations that a fast inactivation of oestrogen receptor occurs in the presence of nuclei from mice oestrogen target-tissues (Auricchio et al., 1980; Auricchio \&Migliaccio, 1980) is confirmed by experiments with calf uterus, a tissue with a large amount of material for the study of this process in vitro.

As regards the exact localization of the receptor-inactivating enzyme it is unlikely that it is associated with uterus nuclear membranes rather than residing within nuclei. In fact, centrifugation after sonification, used to prepare nuclear extracts, should have removed the membranes.

We have preliminarily investigated if the decrease of oestrogen bound to receptor, observed in the presence of the calf-uterus nuclear enzyme using the one-point saturation assay, could be due to an increase in $K_{\mathrm{D}}$ of the receptor-oestradiol complex rather than to a decrease of the number of specific oestrogen binding sites. This possibility is excluded by Scatchard-plot analysis showing that, after incubation of uterus receptor with nuclear activity, the number of specific oestrogen binding sites decreases, whereas no change in affinity of receptor for oestradiol is observed (results not shown).

The receptor-inactivating activity has been purified after extraction from crude nuclei of calf uterus. Its affinity for crude $\left[{ }^{3} \mathrm{H}\right]$ oestrogen-receptor complex, as well as for oestrogen-free receptor, is too high to support a physiological role of this activity in the nuclear turnover of the receptor. Such a role has already been suggested on the basis of the nuclear localization of this activity and its presence only in oestrogen-dependent tissues (Auricchio et al., 1980; Auricchio \& Migliaccio, 1980).

Since proteinases have been found in nuclear preparations from human breast-cancer tissue (Garola \& McGuire, 1977), we have previously investigated the effect of proteinase inhibitors on the inactivation of oestrogen receptor by mouse-uterus nuclei (Auricchio \& Migliaccio, 1980). In our experimental conditions proteinases did not seem responsible for the inactivation of receptor by the nuclear activity. Furthermore the complete prevention of receptor inactivation by phosphatase inhibitors and substrate observed in previous (Auricchio \& Migliaccio, 1980), as well as in present experiments, makes it unlikely that enzymes other than phosphatases are involved in this receptorinactivation process. This also suggests that addition of phosphatase inhibitors to oestrogen-receptor 
preparations could be used to stabilize the hormone-binding activity. Also the dithiothreitol dependence of the nuclear enzyme should suggest a careful use of this substance in the preparation of receptors for analysis, since it might lead to underestimates of oestradiol binding sites.

The possibility that steroid receptor can be inactivated by a dephosphorylation process has been formulated for glucocorticoid receptors (Nielsen et al., 1977). However, in the case of the glucocorticoid receptor only the steroid-free form is inactivated by the intestinal phosphatase whereas in the present experiments the steroid-bound, as well as the steroid-free, receptor appears to be inactivated by a dephosphorylation process. Furthermore the phosphatase deactivating the glucocorticoid receptor has no effect on the oestradiol receptor and it is stimulated by zinc. In addition, it should be stressed that, in some of the present experiments, purified inactivating activity and pure receptor have been used whereas in the case of the glucocorticoid receptor only crude preparations were used. Therefore, whereas for the glucocorticoid receptor it has not been established whether receptor or molecules related to the receptor activity are dephosphorylated, in the present case it appears likely that the dephosphorylated molecule is the oestrogen receptor itself. Finally the present results for the first time show that nuclei inactivate oestrogen receptor by a dephosphorylation process in a system in vitro, and suggest also that in the intact cell a nuclear phosphatase inactivates the oestrogen-receptor complex. Since nuclei have a central role in the mechanism of action of steroid hormones, it is possible that the dephosphorylation of the receptor observed in the present experiments is tightly related to the mechanism of action of oestrogen. We can also hypothesize that the dephosphorylated receptor is recycled by a phosphorylation process, contri- buting in such a way to the cytoplasmic receptor replenishment (Clark \& Peck, 1979).

This research was financially supported by Grant no. 78.2794.96 Progetto Finalizzato; Controllo della Crescita Normale e Neoplastica, CNR, Italy. We gratefully acknowledge the generous gift of pure calf-uterus oestradiol receptor from Dr. G. A. Puca.

\section{References}

Auricchio, F. \& Migliaccio, A. (1980) FEBS Lett. 117, 224-226

Auricchio, F., Migliaccio, A., Sampaolo, P. \& Rotondi, A. (1980) in Perspectives in Steroid Receptor Research (Bresciani, F., ed.), pp. 133-142, Raven Press, New York, in the press

Bradford, M. M. (1976) Analytical Biochem. 72, 248-254

Clark, J. H. \& Peck, E. J. (1979) Female Sex Steroids Receptors and Function, p. 107, Springer-Verlag, Berlin, Heidelberg and New York

Clark, J. H., Anderson, J. N. \& Peck, B. J. (1973) Steroids 22, 707-718

Garola, R. E. \& McGuire, W. L. (1977) Cancer Res. 37, 3329-3332

Giles, K. W. \& Meyers, A. (1965) Nature (London) 206, 93

Horwitz, K. B. \& McGuire, W. L. (1978) J. Biol. Chem. 253, 8185-8191

Nielsen, C. J., Sando, J. J. \& Pratt, W. B.. (1977) Proc. Natl. Acad. Sci. U.S.A. 74, 1398-1402

Puca, G. A., Medici, N., Molinari, A. M., Moncharmont, B., Nola, E. \& Sica, V. (1980) J. Steroid Biochem. 12, 105-113

Rochefort, H., Vignon, F. \& Capony, F. (1972) Biochem. Biophys. Res. Commun. 47, 662-670

Rotondi, A. \& Auricchio, F. (1979) Biochem. J. 178, 581-587

Sarff, M. \& Gorski, J. (1971) Biochemistry 10, 25572563 